\title{
Antral activity and symptom periodicity in duodenal ulceration
}

\author{
L. R. CELESTIN ${ }^{1}$ \\ From Bristol Royal Infirmary
}

EDITORIAL SYNOPSIS A method has been devised for studying the reactivity of the antrum. This is shown to be increased during periods when exacerbation may be associated with changes in cholinergic tone.

The two most important diagnostic features of the duodenal ulcer diathesis are its pain rhythm and its periodicity. During the phase of exacerbation, the pain appears or disappears according to whether the stomach is empty or is full, a rhythm depending on the presence or the absence, in the stomach, of free hydrochloric acid (Palmer, 1926), which is held to be the substance responsible for the initiation of the pain (Pickering, 1951).

The exacerbations themselves are periodic. Day after day, for several weeks, the pain will follow its characteristic rhythm. Then, all of a sudden, it disappears for weeks, months, or even years to be followed by a similar period of symptoms. $X$-ray studies have shown that the ulcer is active when symptoms are present, and that it begins to heal with their disappearance.

If pain is synonymous with activity of the lesion and is triggered off by hydrochloric acid, the question arises as to whether there follows a fall in the foodinduced output of acid when symptoms are ameliorated.

A study undertaken on antral activity in man, in health and in disease, suggests that there exists a relationship between the periodicity of symptoms and antral activity in the duodenal ulcer patient.

Much is known about the antrum in experimental animals by virtue of the ease with which pouch studies can be undertaken in them. By contrast, antral activity in man is still the subject of conjecture based on animal studies. Since cholinergic tone, which sensitizes antral activity, has a species variability, such conjecture may be grossly misleading.

Parietal cell population (Card and Marks, 1960) and reactivity (Stavney, Kato, Savage, Harkins, and Nyhus, 1964), on the other hand, have been extensively studied in man. The parietal cell mass, as ${ }^{1}$ Tutor in surgery, University of Bristol. revealed by the maximal response to histamine, shows a remarkably constant size. It is the target organ of the endocrine system of the stomach and duodenum, and its size would appear to be dependent on the magnitude of the release of the excitatory component of that system, usually gastrin or a gastrin-like substance (Pollacek and Ellison, 1963; Landor, Porterfield, and Wolff, 1966). This would suggest that antral activity plays a dual role in influencing the output of gastric acid secretion: not only does the parietal cell respond to acute stimulation by secreting profusely, but the size of the cell would appear to depend on the level of the chronic stimulation, gastrin acting in this respect like a growth hormone determining the mass of that cell. Once the maximal hyperplasia or hypertrophy has been reached, the cell mass would remain fairly constant. Hence any fluctuation in its secretory output must be the result of a fluctuation in endocrine release, either excitatory or inhibitory.

The exogenous administration of gastrin throws no light on antral physiology; and as blood levels of gastrin cannot as yet be determined precisely, antral activity can only be studied by indirectly observing the effects of the release of endogenous gastrin by means of a fixed antral stimulus.

The best antral stimulant is a meat broth. It excites the antrum mechanically, by virtue of its bulk, and chemically, by virtue of its hydrolysed protein contents. The eventual output of $\mathbf{H}$ ions by the oxyntic cells is the product of the food-induced gastrin and the parietal cell mass. It is thus essential that the size of the latter be known.

We therefore decided to study in man three factors in gastric secretion: antral response to mechanical stimulation, antral response to chemical stimulation, and peak secretory capacity of the parietal cell population.

We also tried to reproduce, as best as is possible 
experimentally, a state in the duodenum and antrum comparable to that prevailing when a small amount of food is ingested.

\section{MATERIAL}

The subjects were divided into three groups:

A Normals, being patients with no gastrointestinal disorder; B patients with quiescent duodenal ulceration at the time of the study, quiescence being defined as total freedom from symptoms for three weeks preceding the test, without medication; $\mathrm{C}$ patients with active duodenal ulceration, that is, having symptoms of several weeks' duration not fully controlled by antacid therapy.

Since it was not always easy to admit patients at such times as they fulfilled the above conditions, the numbers investigated are of necessity limited. Each test, lasting six to eight hours, inflicts on the patient a fair amount of discomfort, and further limits one's choice and numbers.

In all, 20 patients were studied: five in each of groups A and $B$, and 10 in group C. All groups contained patients of comparable ages; and all patients with duodenal ulceration were proven cases, either by radiography or by surgery, or, as it was in the majority of cases, by both. Cases A4 and B4 were females.

(In addition to the studies on antral activity, studies on the effect of duodenal acidification were also carried out in these patients. The results will be the subject of a later report.)

\section{METHOD}

A modification of a tube devised by Marks to study secretion after Polya gastrectomy was used (Marks, 1957). A four-lumen tube carries a weighted mercury bag above which opens one of the lumens. This is for acidification of the duodenum, or for aspiration of duodenal contents. Two other lumens open inside adjacent balloons enclosed in a third common balloon (Fig. 1). The distal balloon is inflated within the duodenum, and the proximal one within the antrum. They stretch the third one across them and snugly occlude the pylorus. No acid can therefore escare into the duodenum, nor can duodenal contents regurgitate into the stomach. The fourth lumen collects gastric secretion and is provided with five or six side holes. Radio-opaque markers delineate the positions of the balloons and facilitate fluoroscopy.

The patient has his last meal of the day at about 6 p.m. At 9 p.m. the tongue and throat are sprayed with a $4 \%$ xylocaine solution, and a few minutes later the tube is quickly slipped past the pharynx into the oesophagus, after which the patient swallows the tube to its $60 \mathrm{~cm}$. mark. He lies on his right side, appropriately bolstered, until the morning. The tube is advanced $5 \mathrm{~cm}$. every half hour until the $90 \mathrm{~cm}$. mark is reached. At 9 a.m. the next day, the position of the tube is visualized on the image intensifier screen. As a rule, the mercury bag is found to lie in the second to fourth part of the duodenum (Fig. 2). The duodenal balloon is then partially inflated with a $10 \%$ Hypaque solution, and withdrawn under direct vision until it lies in the duodenal bulb. It is then inflated to a total of $15 \mathrm{ml}$. which gives it a diameter of under

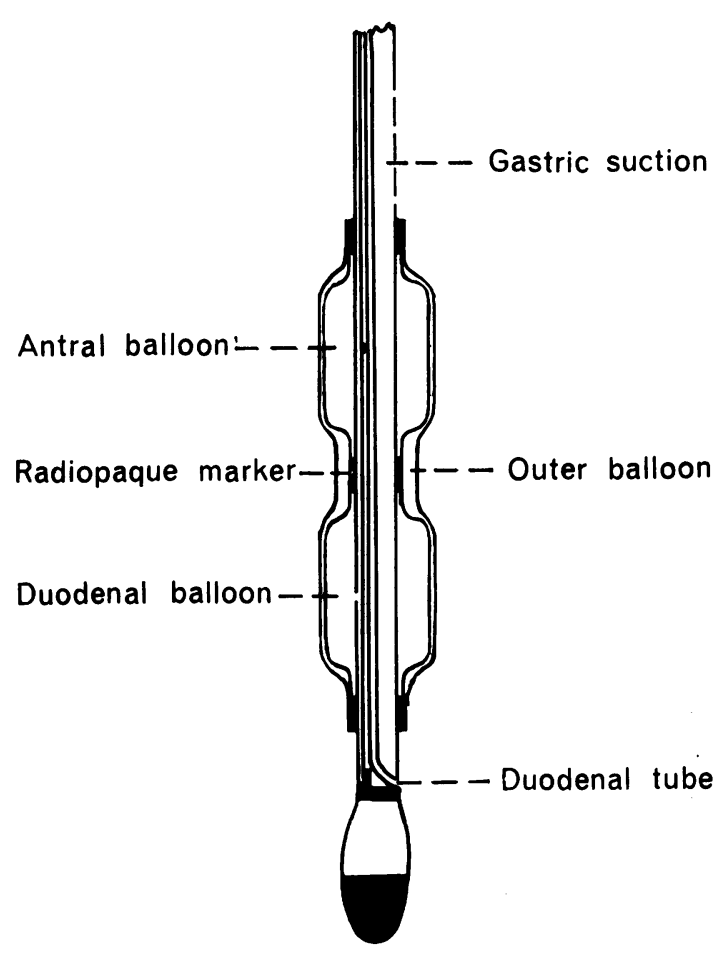

FIG. 1. Tube used for gastric aspiration.

$2.5 \mathrm{~cm}$. The tube is then further withdrawn until the balloon abuts the pylorus and tension is felt. The antral balloon is now blown up with $20 \mathrm{ml}$. of Hypaque solution. Some 8 to $10 \mathrm{~cm}$. of the tube is advanced into the stomach, when it will tend to lie along the greater curve (Fig. 3). The patient is now ready for the studies.

The volume of all secretions was accurately measured to the nearest millilitre. Their free and total acid contents were determined by titration against $\mathrm{N} / 10 \mathrm{NaOH}$ using Topfer's reagent as indicator. Their $p \mathrm{H}$ in the fresh state was metered. All specimens were tested for bile at the time of aspiration, using Ictotest tablets. Most showed absence of bile, and only a few showed traces. Suction was by an electrically driven pump with a bleeding valve, a vacuum of $15 \mathrm{~cm}$. $\mathrm{Hg}$ being aimed at. Rigid minute-tominute monitoring of the continuous suction was personally carried out throughout the whole study.

Histamine was administered intravenously at the rate of $5 \mathrm{mg}$. per hour, using a Woolmer constant infusion pump.

The meat broth used consisted of a standard Bovril solution prepared by diluting $15 \mathrm{ml}$. of the commercial concentrate with water to a total of $400 \mathrm{ml}$. and left at its natural $p \mathrm{H}$ of $5 \cdot 5$.

\section{STUDY}

Antral distension by the balloon constitutes mechanical stimulation. The secretion resulting from this takes at least half an hour before reaching a steady state, which 


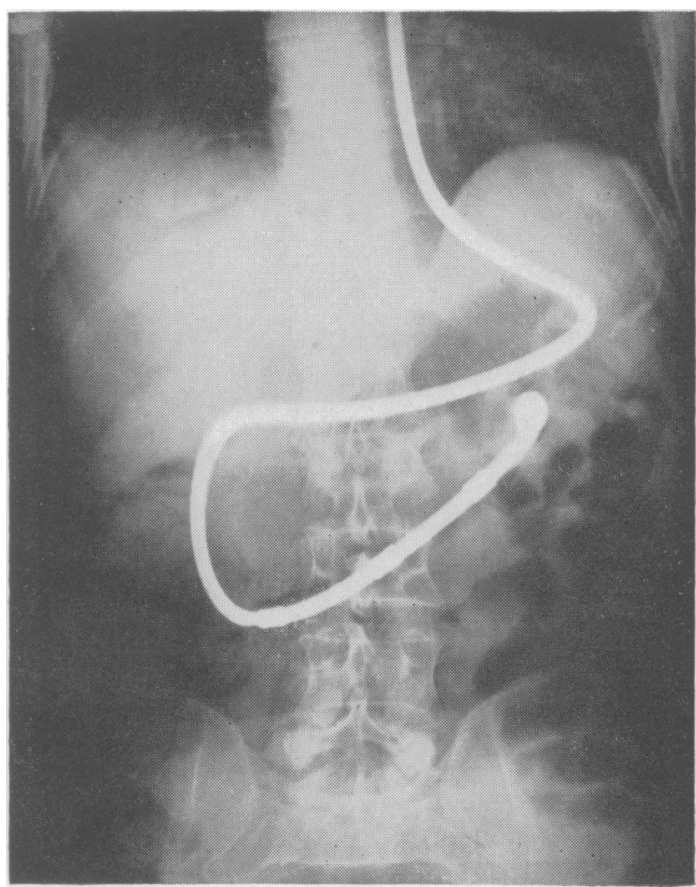

FIG. 2.

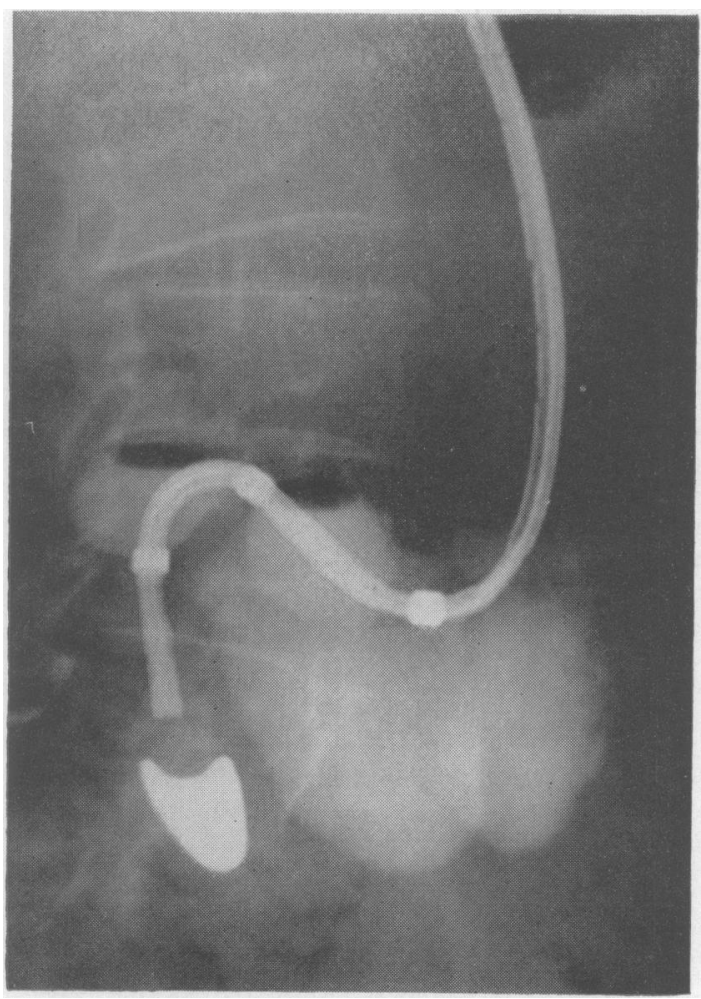

FIG. 4.

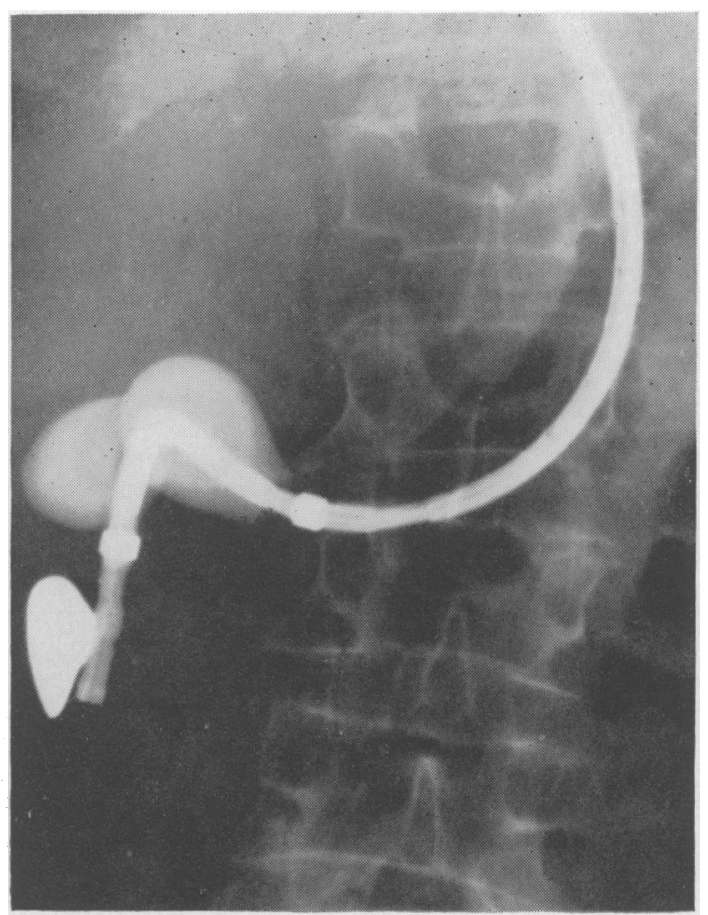

FIG. 3.

FIG. 2. Initial position of the tube showing radio-opaque markers.

FIG. 3. The tube in its antro-duodenal position with balloons inflated.

FIG. 4. One hundred $\mathrm{ml}$. of broth fills the antrum to the level of the incisura. 
is arrived at when two consecutive five-minute specimens differ by less than $2 \mathrm{ml}$. A 15-minute sample is collected. This is the response to mechanical stimulation.

Bovril broth, $100 \mathrm{ml}$., at room temperature, is now instilled in the stomach and left for 15 minutes, after which the stomach is completely emptied, and the aspirated volume checked to see that it is greater than $100 \mathrm{ml}$. During the period of instillation small samples of duodenal contents were collected to check on any leakage of the broth. On no occasion was this detected. It is essential that no broth be left in the stomach before proceeding to the next part of the investigation.

The secretion over the ensuing 15 minutes is deemed to be that resulting from the combined effect of mechanical and chemical stimulations. Since $100 \mathrm{ml}$. of broth distends the antrum more than does the antral balloon (Fig. 4), this secretion, for convenience, will be referred to as that resulting from chemical stimulation. This chemically induced secretion is allowed to subside completely before the next step is taken. Some two hours have to elapse before there is a return to the steady-state level of mechanical stimulation. The studies on duodenal acidification take place at this stage, and again, a period of rest is allowed before a return to the baseline of mechanical stimulation. Histamine infusion is then started.

Mepyramine maleate, $50 \mathrm{mg}$., is given intramuscularly 30 minutes before starting the histamine infusion. This is continued until the steady state is reached, when a 15-minute sample is collected. This is the peak secretory output of the cell mass over that time. The collection of this sample ends the investigation.

All results-volumes, acid concentrations, and outputs - are expressed on an hourly basis. The values for free acidity are given in Table $\mathbf{I}$. Values for total acidity did not contribute any further information, and are not given here. (They can be obtained from the author if requested.) The effect of chemical stimulation expressed as a perentage of the maximal secretory capacity of the oxyntic cells is shown in the last column.

A visual comparison of the effects of mechanical and of chemical stimulations in the three groups is shown in Figure 5.

\section{DISCUSSION}

METHOD Objections can be raised that the nature of the tube vitiates the results. The presence of a tube irritating the nose, pharynx, and oesophagus is known to stimulate gastric secretion (Branisteau, Strat, and Fainita, 1934), as also does its direct mechanical effect on the gastric mucosa (Bezborodko and Voronova, 1938). This is common to all investigations using tubes and has to be accepted. If the irritation causes nausea, secretion is markedly inhibited (Grossman, Woolley, Dutton, and Ivy, 1945). For this reason we pass the tube the night before so that by the morning the patient has become used to the irritation and no longer feels nauseated.

Moderate distension of the duodenum causes a noticeable stimulation of gastric secretion (Sircus, 1953; Nagano, Johnson, Cobo, Oberhelman, and Dragstedt, 1960), and the duodenal balloon will very likely act in that manner in our investigations. But this is the state prevailing when food enters the duodenum and distends it to a diameter of over $2.5 \mathrm{~cm}$. It is the state to be expected under normal

\begin{tabular}{|c|c|c|c|c|c|c|c|c|c|}
\hline \multirow[t]{2}{*}{ Group } & \multirow{2}{*}{$\begin{array}{l}\text { Case } \\
\text { No. }\end{array}$} & \multicolumn{3}{|c|}{ Mechanical } & \multicolumn{3}{|c|}{ Chemical } & \multirow{2}{*}{$\begin{array}{l}\text { Histamine } \\
(m E q . / h r .)\end{array}$} & \multirow{2}{*}{$\begin{array}{l}\text { Broth/Hist. } \\
(\%)\end{array}$} \\
\hline & & Vol./hr. & $m E q . / l$. & $m E q . / h r$. & Vol./hr. & $m E q . / l$. & $m E q . / h r$ & & \\
\hline $\begin{array}{l}\mathbf{A} \\
\mathbf{A} \\
\mathbf{A} \\
\mathbf{A} \\
\mathbf{A}\end{array}$ & $\begin{array}{c}1 \\
2 \\
3 \\
4 \\
5 \\
\text { Means }\end{array}$ & $\begin{array}{r}44 \\
186 \\
171 \\
62 \\
28 \\
98\end{array}$ & $\begin{array}{l}64 \\
43 \\
27 \\
12 \\
40 \\
37\end{array}$ & $\begin{array}{l}2 \cdot 8 \\
8 \cdot 2 \\
4 \cdot 6 \\
0 \cdot 74 \\
1 \cdot 1 \\
3 \cdot 5\end{array}$ & $\begin{array}{r}62 \\
100 \\
152 \\
140 \\
116 \\
114\end{array}$ & $\begin{array}{l}66 \\
96 \\
32 \\
56 \\
36 \\
57\end{array}$ & $\begin{array}{l}4 \cdot 1 \\
9 \cdot 6 \\
4 \cdot 9 \\
7 \cdot 8 \\
4 \cdot 2 \\
6 \cdot 1\end{array}$ & $\begin{array}{l}11 \cdot 8 \\
20 \cdot 6 \\
21 \cdot 8 \\
17 \cdot 2 \\
16 \cdot 8 \\
17 \cdot 6\end{array}$ & $\begin{array}{l}34 \cdot 8 \\
45 \cdot 6 \\
22 \cdot 9 \\
45 \cdot 3 \\
25 \\
34 \cdot 9\end{array}$ \\
\hline $\begin{array}{l}\mathbf{B} \\
\mathbf{B} \\
\mathbf{B} \\
\mathbf{B} \\
\mathbf{B} \\
\mathbf{B}\end{array}$ & $\begin{array}{c}\text { Means } \\
1 \\
2 \\
3 \\
4 \\
5 \\
\text { Means }\end{array}$ & $\begin{array}{r}75 \\
20 \\
192 \\
32 \\
60 \\
72 \\
75\end{array}$ & $\begin{array}{l}31 \\
20 \\
54 \\
44 \\
22 \\
13 \\
31\end{array}$ & $\begin{array}{r}2.9 \\
0.4 \\
10.4 \\
1.4 \\
1.3 \\
0.9 \\
2.9\end{array}$ & $\begin{array}{l}185 \\
144 \\
210 \\
210 \\
164 \\
148 \\
185\end{array}$ & $\begin{array}{l}71 \\
80 \\
66 \\
64 \\
64 \\
79 \\
71\end{array}$ & $\begin{array}{l}12.2 \\
11.5 \\
13.9 \\
13.4 \\
10.5 \\
11.7 \\
12.2\end{array}$ & $\begin{array}{l}43 \cdot 1 \\
41 \cdot 5 \\
41 \cdot 3 \\
65 \cdot 5 \\
36 \cdot 8 \\
30 \cdot 5 \\
43 \cdot 1\end{array}$ & $\begin{array}{l}31 \cdot 7 \\
27 \cdot 7 \\
33 \cdot 6 \\
20 \cdot 5 \\
28 \cdot 6 \\
38 \cdot 4 \\
31 \cdot 7\end{array}$ \\
\hline $\begin{array}{l}C \\
C \\
C \\
C \\
C \\
C \\
C \\
C \\
C \\
C \\
C\end{array}$ & $\begin{array}{c}\text { Means } \\
1 \\
2 \\
3 \\
4 \\
5 \\
6 \\
7 \\
8 \\
9 \\
10 \\
\text { Means }\end{array}$ & $\begin{array}{r}208 \\
72 \\
196 \\
172 \\
172 \\
784 \\
120 \\
176 \\
170 \\
136 \\
78 \\
208\end{array}$ & $\begin{array}{r}49 \\
14 \\
104 \\
60 \\
22 \\
20 \\
52 \\
55 \\
38 \\
64 \\
58 \\
49\end{array}$ & $\begin{array}{r}8 \cdot 6 \\
1 \\
20 \cdot 4 \\
10 \cdot 3 \\
3.8 \\
15 \cdot 7 \\
6 \cdot 2 \\
9 \cdot 7 \\
6 \cdot 5 \\
8 \cdot 7 \\
4.5 \\
8.6\end{array}$ & $\begin{array}{l}281 \\
280 \\
236 \\
240 \\
224 \\
200 \\
244 \\
432 \\
400 \\
411 \\
144 \\
281\end{array}$ & $\begin{array}{r}88 \\
76 \\
90 \\
110 \\
54 \\
96 \\
110 \\
100 \\
56 \\
88 \\
104 \\
88\end{array}$ & $\begin{array}{l}24 \cdot 8 \\
25 \cdot 5 \\
21 \\
26 \cdot 4 \\
12 \cdot 1 \\
19 \cdot 2 \\
27 \cdot 1 \\
43 \cdot 2 \\
22 \cdot 4 \\
36 \cdot 2 \\
14 \cdot 9 \\
24 \cdot 8\end{array}$ & $\begin{array}{l}31 \cdot 3 \\
27 \cdot 2 \\
34 \cdot 5 \\
43 \cdot 6 \\
14 \cdot 7 \\
25 \cdot 8 \\
34 \cdot 3 \\
44 \cdot 1 \\
28 \cdot 4 \\
36 \cdot 3 \\
21 \cdot 3 \\
31 \cdot 3\end{array}$ & $\begin{array}{c}79 \cdot 8 \\
94 \cdot 1 \\
60 \cdot 9 \\
61 \cdot 9 \\
82 \cdot 3 \\
74 \cdot 4 \\
79 \\
98 \\
78 \cdot 8 \\
100 \\
70 \\
79 \cdot 8\end{array}$ \\
\hline
\end{tabular}

TABLE I 


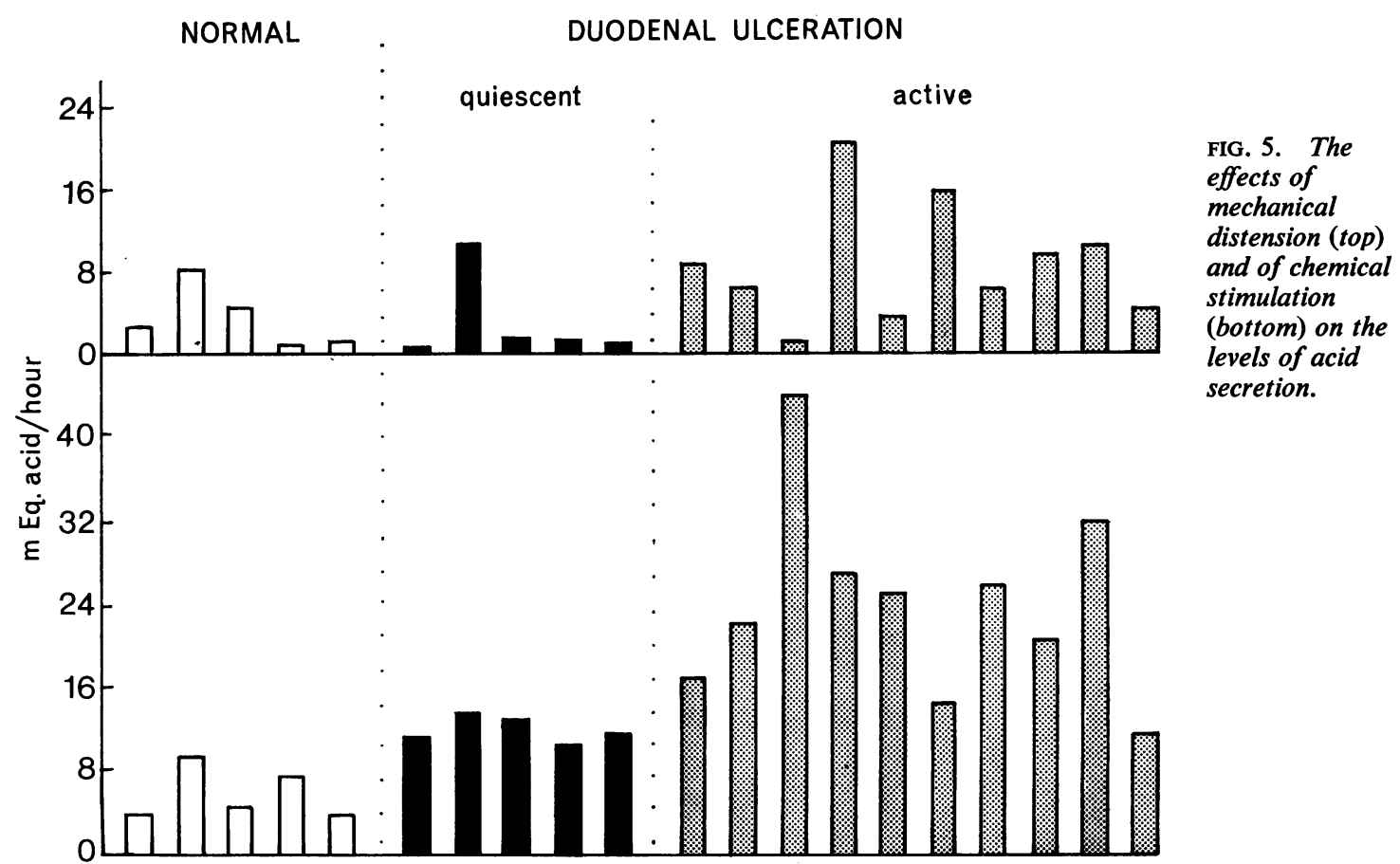

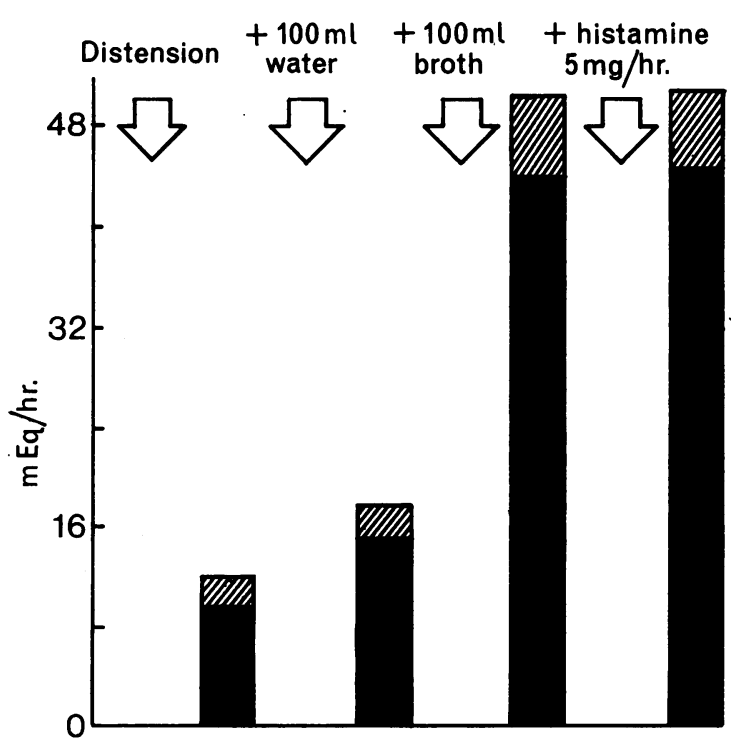

FIG. 6. The effect of mechanical stimulation by $100 \mathrm{ml}$. of water compared with that caused by chemical stimulation by a same volume of broth. The hatched area takes the 'free' acid column to the level of 'total' acidity. physiological conditions, and which when reproduced (as by a balloon) adds precisely to the effects we want to study, namely, the release of endogenous gastric excitants. The abnormal state is the one in which duodenum and stomach are made to secrete when empty.

It could be argued that the balloon distending the antrum sensitizes the latter to chemical stimulation and introduces an unacceptable factor. In the pilot work before the present study, it was found that $100 \mathrm{ml}$. of Hypaque filled the antrum to the level of the incisura, and distended it more than did the balloon (Fig. 4). This also ensured that the whole antral mucosa was bathed by the broth. It was also observed that the mechanical stimulation caused by a volume of $100 \mathrm{ml}$. of distilled water induced in patients with duodenal ulcer a secretion about onethird that promoted by $100 \mathrm{ml}$. of broth (Fig. 6). Any mechanical effect of the balloon is therefore overshadowed by that of the bulk of the broth.

Whatever objections may be raised against the use of occluding balloons, they are more than compensated by the fact that they prevent the escape of acid into the duodenum. Such an acidification inhibits gastric secretion of the oxyntic cells by a figure as little as $5 \%$ or as high as $76 \%$ and makes results unreliable, since all measurements are made against a background of changing inhibition. Similarly, reflux of duodenal contents into the 
stomach will alter the response of the antral mucosa. The only reliable results are therefore those of workers who have gone to enormous trouble to carry out their tests under conditions free from such interference.

RESULTS There is a wide variation of response to mechanical stimulation in all three groups (Fig. 5). Chemical stimulation gives a more uniform response (Fig. 5). By far the most striking feature is the manner in which the quiescent patient with duodenal ulcer follows the pattern of response of the normal person. The secretion induced by mechanical stimulation shows, in both groups, a similarity in volume and in acid concentration, and therefore in the hourly output. The active ulcer group shows much higher figures in all respects. Of note is the fact that the hourly output to mechanical stimulation in that group is even higher than the hourly output to chemical stimulation in normal subjects.

The responses to chemical stimulation in groups $A, B$, and $C$ are in the ratio $1: 2: 4$. When these responses are expressed as a percentage of the maximal secretory activity of their respective stomachs, it transpires, when groups A and B are compared, that the latter's twofold higher output is due largely to its correspondingly greater parietal cell mass. This suggests that the antra of these two groups have comparable activities. Group $\mathrm{C}$, on the other hand, shows a fourfold higher response than group A for a twofold higher parietal cell mass. It has, therefore, an increased activity of both its oxyntic cells and its antrum.

The means of the responses of the three groups to histamine, and to broth, as well as their respective standard deviations, are shown in Table II. When the trustworthiness of these results is subjected to statistical analysis, the differences between the groups, compared in turn, are found to be significant (Table III). Group B, however, remains hallmarked by a secretion of less than $15 \mathrm{mEq}$. per hour in response to chemical stimulation. This would appear to be the level below which acid output must fall for healing to take place as revealed by freedom from symptoms. In active duodenal ulceration, on the other hand, the hour output reaches maximum or near-maximum levels in the majority of patients. There is therefore a very definite difference between the two groups in their food-induced acid secretion and its relationship to symptoms. Furthermore, it would seem that the maximal secretory capacity required to produce ulceration need not be much higher than $15 \mathrm{mEq}$. per hour, a fact of unifying importance in the acid concept of ulcer diathesis, whereby 'hypersecretors' are no different from 'hyposecretors'. The hypersecretor is simply some-
TABLE II

MEANS AND STANDARD DEVIATIONS OF RESPONSES TO HISTAMINE AND TO BROTH STIMULATION

\begin{tabular}{llll} 
Stimulus & \multicolumn{3}{l}{ Group } \\
\cline { 2 - 4 } & Normal & Quiescent & Active \\
\hline Histamine & $17.64 \pm 3.91$ & $43.12 \pm 13.29$ & $31.02 \pm 9.37$ \\
Chemical & $6.12 \pm 2.46$ & $12.20 \pm 1.41$ & $24.80 \pm 9.36$
\end{tabular}

TABLE III

COMPARISONS BETWEEN THE THREE GROUPS WITH THEIR SIGNIFICANCE

\begin{tabular}{llll} 
Stimulus & Group & \\
\cline { 2 - 4 } & Normal/Active & Normal/Quiescent & Quiescent/Active \\
\hline Histamine & $\begin{array}{l}\text { Highly } \\
\text { significant }\end{array}$ & $\begin{array}{l}\text { Highly } \\
\text { significant } \\
(\mathrm{P}<0.001)\end{array}$ & $\begin{array}{l}\text { Not } \\
\text { significant }\end{array}$ \\
Chemical & $\begin{array}{l}\text { Highly } \\
\text { significant } \\
(\mathrm{P}<0.001)\end{array}$ & $\begin{array}{l}\text { Significant } \\
(\mathrm{P}<0.01)\end{array}$ & $\begin{array}{l}\text { Significant } \\
(\mathrm{P}<0.01)\end{array}$ \\
& $\begin{array}{l}\text { (P }) \\
\end{array}$ & &
\end{tabular}

one who has a more marked parietal cell mass hyperplasia. Likewise, a maximal histamine response of well over $15 \mathrm{mEq}$. per hour need not indicate a proneness to duodenal ulceration if the antrum is of 'normal' activity. This is the probable explanation of the wide range encountered in maximal histamine tests, and emphasizes a great drawback in seeking to reach physiological conclusions from the administration of unphysiological doses of exogenous stimulants.

\section{CONCLUSION}

The response of the antrum to stimulation is markedly influenced by its cholinergic tone (Uvnäs, 1942; Grossman, Robertson, and Ivy, 1948). Vagal tone is essential to the proper functioning of the antrum (Forrest, 1956), while vagal stimulation by physiological means will release gastrin (Pe Thein and Schofield, 1959). If subthreshold doses of urecholine are administered to an animal with an intact stomach there results an increased release of gastrin from local antral stimulation (Gregory and Tracy, 1960). Conversely, atropine inhibits the release of gastrin, as does the ganglionic blocking agent hexamethonium (Redford and Schofield, 1963).

Antral activity thus shows great dependence on cholinergic tone, which is a labile factor. Parietal maximal secretory capacity, on the other hand, varies little in an innervated stomach. Yet, as already said, the greatest characteristic of duodenal ulcer diathesis is its periodicity. Could this be explained by the fact that the physiological levels of secretion vary according to a labile antral activity? The above 
study seems to indicate that there is a distinct increase in antral activity during periods of exacerbation, while during quiescence the antrum behaves in a manner similar to the normal. This would fit well with changes in cholinergic tone.

'Cephalic' and 'hormonal' phases are therefore indivisible, and to look upon them as separate entities can but confuse the proper understanding of gastric physiology and its bearing on peptic ulceration. Endocrine and exocrine functions are closely integrated in the proper regulation of that physiology, the health of which requires a normal cholinergic tone.

\section{SUMMARY}

Antral activity in man was studied in normal subjects, and in patients with quiescent and with active duodenal ulcers.

Normal and quiescent duodenal ulcer patients show similar antral activity, whereas it is increased in the patient with an active duodenal ulcer.

It is suggested that the episodic nature of duodenal ulceration depends on variations in antral activity, and that healing of an ulcer takes place when the response to antral stimulation by food produces a parietal cell output of less than $15 \mathrm{mEq}$. per hour. In this respect, there is no difference between socalled hyposecretors and hypersecretors.

I am indebted to Mr. W. M. Capper for guidance with this work; to Professor A. G. Riddell for helpful criticism; and to Sister A. Chibbett and her staff for their patient cooperation during the tests.

\section{REFERENCES}

Bezborodko, A., and Voronova, V. A. (1938). A comparative evaluation of the action of mechanical and chemical stimuli on the function of the gastric glands. In Studies on the Physiology and Patho-physiology of the Digestive Apparatus of Man, edited by $K$. M. Bykov, vol. 4, p. 21. (In Russian.) Moscow and Leningrad. Quoted by Babkin, B. P. (1950), Secretory Mechanism of the Digestive Glands, 2nd ed., pp. 155, 211. Cassell, London.

Branisteanu, D., Strat, C. C., and Fainita, D. I. (1934). Sur la sécrétion gastrique provoquée par la sonde duodénale. Arch. Mal. Appar. dig., 24, 180-197.

Card, W. I., and Marks, I. N. (1960). The relationship between the acid output of the stomach following 'maximal' histamine stimulation and the parietal cell mass. Clin. Sci., 19, 147-163.

Forrest, A. P. M. (1956). In Abstracts of communications, XXth int. Physiol. Congr., p. 299.

Gregory, R. A., and Tracy, H. J. (1960). Secretory responses of denervated gastric pouches. Amer. J. dig. Dis., 5, 308-323.

Grossman, M. I., Robertson, C. R., and Ivy, A. C. (1948). Proof of hormonal mechanism for gastric secretion; humoral transmission of distension stimulus. Amer. J. Physiol., 153, 1-9.

- Woolley, J. R., Dutton, D. F., and Ivy, A. C. (1945). The effect of nausea on gastric secretion and a study of the mechanism concerned. Gastroenterology, 4, 347-351.

Landor, J. H., Porterfield, J. F., and Wolff, W. S. (1966). The parietal cell response to chronic gastric secretory stimulation. Surg. Gynec. Obstet., 122, 61-65.

Marks, I. N. (1957). The significance of the gastric secretion after partial gastrectomy and gastroenterostomy; with description of a method for determining the acid output. Amer. J. Gastroent., 27, 566-583.

Maung Pe Thein, and Schofield, B. (1959). Release of gastrin from the pyloric antrum following vagal stimulation by sham feeding in dogs. J. Physiol. (Lond.), 148, 291-305.

Nagano, K., Johnson, A. N., Jr., Cobo, A., Oberhelman, H. A., Jr., and Dragstedt, L. R. (1960). The effect of distension of the duodenum on gastric secretion. Surg. Forum, 10, 152-155.

Palmer, W. L. (1926). The mechanism of pain in gastric and in duodenal ulcer. II. The production of pain by means of chemical irritants. Arch. intern. Med., 38, 694-707.

Pickering, G. W. (1951). Peptic ulcer. Newc. med. J., 24, 49-66.

Polacek, M. A., and Ellison, E. H. (1963). A comparative study of parietal cell mass and distribution in normal stomachs, in stomachs with duodenal ulcer, and in stomachs of patients with pancreatic adenoma. Surg. Forum, 14, 313-315.

Redford, M., and Schofield, B. (1963). Pharmacological investigation of the gastric release mechanism. (Abstract.) Biochem. Pharmacol., suppl. to vol. 12 , no. 453 .

Stavney, L. S., Kato, T., Savage, L. E., Harkins, H. N., and Nyhus, L. M. (1964). Parietal cell reactivity. Surg. Gynec. Obstet., 118, 1269-1272.

Sircus, W. (1953). The intestinal phase of gastric secretion. Quart. J. exp. Physiol., 38, 91-100.

Uvnäs, B. (1942). The part played by the pyloric region in the cephalic phase of gastric secretion. Acta physiol. scand., 4, suppl. 13. 